\title{
Biopsy of Pericardium
}

National Cancer Institute

\section{Source}

National Cancer Institute. Biopsy of Pericardium. NCI Thesaurus. Code C51568.

Removal of tissue from the pericardium for microscopic examination. 